\title{
THE
}

\section{Financial capability and wellbeing of vulnerable consumers}

Jing Jian Xiao

University of Rhode Island, jjxiao@uri.edu

Nilton Porto

University of Rhode Island, nilton_porto@uri.edu

Follow this and additional works at: https://digitalcommons.uri.edu/hdf_facpubs

The University of Rhode Island Faculty have made this article openly available.

Please let us know how Open Access to this research benefits you.

This is a pre-publication author manuscript of the final, published article.

Terms of Use

This article is made available under the terms and conditions applicable towards Open Access Policy Articles, as set forth in our Terms of Use.

\section{Citation/Publisher Attribution}

Xiao, J. J., \& Porto, N. (2021). Financial capability and wellbeing of vulnerable consumers. Journal of Consumer Affairs, 1- 15. https://doi.org/10.1111/joca.12418

Available at: https://doi.org/10.1111/joca.12418

This Article is brought to you for free and open access by the Human Development and Family Science at DigitalCommons@URI. It has been accepted for inclusion in Human Development and Family Science Faculty Publications by an authorized administrator of DigitalCommons@URI. For more information, please contact digitalcommons@etal.uri.edu. 


\title{
Financial capability and wellbeing of vulnerable consumers
}

\author{
Jing Jian Xiao PhD \\ Professor \\ xiao@uri.edu \\ Nilton Porto MBA, PhD \\ Associate Professor \\ nilton_porto@uri.edu \\ Department of Human Development and Family Science \\ University of Rhode Island \\ 2 Lower College Road \\ Kingston, RI 02881, USA
}

\section{Correspondence}

Jing Jian Xiao, Department of Human Development and Family Science, University of Rhode Island, 2 Lower College Road, Kingston, RI 02881

Email: jjxiao@uri.edu

Jing Jian Xiao, Ph.D., is a professor of consumer finance in the Department of Human Development and Family Studies at the University of Rhode Island. He has published research papers on consumer financial capability and wellbeing and books including Handbook of Consumer Finance Research and Consumer Economic Wellbeing. He received his Ph.D. in consumer economics from the Oregon State University.

Nilton Porto, Ph.D., is an associate professor of consumer finance in the Department of Human Development and Family Studies at the University of Rhode Island. He received his MBA from Case Western Reserve University and Ph.D. in consumer science from the University of Wisconsin-Madison. 


\title{
Financial Capability and Financial Wellbeing of Vulnerable Consumers
}

\begin{abstract}
Consumer financial capability can be defined variously by different researchers. In this study, financial capability is assumed to have three components, financial knowledge, financial behavior, and financial skills. This study examines relative contributions of financial capability components to financial wellbeing among vulnerable consumers. With data from the National Financial Wellbeing Survey commissioned by the Consumer Financial Protection Bureau (CFPB), results show that among financial capability components, financial behavior contributes the most to financial wellbeing of the whole sample, followed by financial skill and financial knowledge. In addition, group differences surface when subsamples in terms of age, poverty status, confidence, and fraud victim status are examined. Results suggest that for low-income consumers, encouraging them to engage in desirable financial behaviors is more important than teaching them financial knowledge and skills. Findings have implications for financial educators, practitioners, and policymakers to help them recognize the proper financial education or program to be delivered based on consumer vulnerability and components of financial capability.
\end{abstract}

\section{KEYWORDS:}

financial capability, financial wellbeing, vulnerable consumers 


\section{INTRODUCTION}

Consumer financial capability is a broad concept that includes financial knowledge, resources, access, and habits (Lin et al., 2016). Financial capability sometimes refers to financial literacy (Lusardi \& Mitchell, 2014) and its applications (Huston, 2010). Some researchers have defined financial capability as an individual's ability to manage their finances effectively (Taylor, 2011). As an individual ability, financial capability includes financial knowledge and financial behavior (Xiao \& O’Neill, 2016; Xiao \& Porto, 2017). Financial skill is also considered a component of financial capability (CFPB, 2017). Associations between financial wellbeing and financial capability factors such as financial knowledge and financial behavior are examined by previous research (Hilgert et al. 2003; Robb \& Woodyard 2011; Shapiro \& Burchell, 2012; Tang et al. 2015; Xiao, Serido, \& Shim, 2011a; Xiao, Tang, Serido, \& Shim, 2011b). Research on the association between financial skill and financial wellbeing is emerging (CFPB, 2018;

Bialowolski, Cwynar, \& Cwynar, 2020). However, no previous research examined relative contributions of individual financial capability factors such as financial knowledge, financial behavior, and financial skill, to the financial wellbeing of vulnerable consumers. In other words, comparatively, which factor, financial knowledge, financial behavior, or financial skill is more closely associated with financial wellbeing? This study is to fill this gap. Results of this study have direct implications for consumer financial education design and delivery.

Consumer vulnerability is defined as "a state in which consumers are subject to harm because their access to and control over resources are restricted in ways that significantly inhibit their ability to function in the marketplace" (Hill \& Sharma, 2020, p.551). Consumer vulnerability has been recognized as a dynamic and transient state where not all people experience vulnerability in the same manner (Baker, Gentry, \& Rittenburg, 2005; Commuri \& Ekici, 2008). Mick, 
Pettigrew, Pechmann, and Ozanne (2012) in a book on transformative consumer research, put together a progressive definition of vulnerability using demographic, environmental, situational, and community and context factors. This study focused on consumer wellbeing and examined consumer wellbeing among consumers with an emphasis on vulnerable consumers from a static perspective.

A vulnerable consumer is someone who, due to their personal circumstances, is especially susceptible to detriments (Coppack, Raza, Sarkar, \& Scribbins, 2015). Consumers could be vulnerable in various dimensions such as demographic, economic, psychological, and social. In this study, we focus on four factors that represent these dimensions: age, poverty status, confidence, and fraud victim status. Based on these factors, vulnerable consumers are categorized as the young, the poor, those who lack confidence in achieving their financial goals, and fraud victims. These vulnerable groups may require special attention from policymakers and educators to help enhance their financial capability and improve their financial wellbeing. Consumer financial educators, for instance, may need to adjust accordingly to deliver effective programs to vulnerable groups at schools, workplaces, and communities.

Researchers on financial capability believe that consumers with higher financial capability are more likely to achieve consumer wellbeing (e.g. CFPB, 2017, 2018). Consumer financial capability is defined by researchers in different ways. Some researchers emphasize financial literacy (Lusardi \& Mitchell, 2014) or behavior (Atkinson, McKay, Collard, \& Kempson, 2007). Besides knowledge and behavior, some researchers use more components such as skills and confidence (Bialowolski et al., 2020). In addition, some researchers include both personal ability and policy supported access to affordable and suitable financial products (Johnson \& Sherraden, 
2007). In this study, financial capability is considered a personal ability and defined as applying appropriate financial knowledge, engaging in desirable financial behaviors, and utilizing suitable financial skills for achieving financial wellbeing. This definition is an extension of the definition used by Xiao et al. (2014) that includes two components, knowledge and behavior, and added one more component, skill, based on the work by CFPB (2017). In the research literature, studies separating knowledge and skill are rare with a few exceptions (e.g. Bialowolski et al., 2020). This study contributes to the literature by including skill as a component to financial capability. However, skill in this study means the perceived ability to manage finances, which is different from other studies that used skill in a numeric fashion such as to calculate debt problems (Bialowolski et al., 2020). Based on this definition, financial capability has three components: knowledge, behavior, and skill. These components are compared when they are correlated with financial wellbeing and relatively important factors are identified for the whole sample and selected subsamples, especially those who are vulnerable in socioeconomic statuses.

This study makes unique conceptual contributions to the literature of financial capability. In previous research, interactions between financial capability components are examined (e.g., Shim, Barber, Card, Xiao, \& Serido, 2010; Xiao et al., 2011a). In this study, we assume that these components are equal contributors to consumer financial wellbeing and test this assumption with nationally representative data. The results show that these factors may interact to each other through complex interactions, but they also make their unique contributions to the outcome variable, consumer financial wellbeing. The advantage of this approach is to provide straightforward results that can be used by practitioners immediately.

The original plan for designing this study is to provide results that can be useful for practitioners. 
The findings have practical implications for consumer financial education. For example, if financial behavior is found to be a more important contributor than financial knowledge for a vulnerable population's financial wellbeing, then consumer educators may spend more time to encourage action taking for a specific financial behavior instead of explaining complex financial equation calculation.

\section{PREVIOUS RESEARCH AND RESEARCH QUESTIONS}

\subsection{Financial wellbeing}

Financial wellbeing can be measured in various ways such as with objective vs. subjective measures, and one-item vs. multi-item measures (Xiao, 2015). Researchers have proposed various definitions of financial wellbeing (Joo, 2008). The CFPB has recently proposed a definition of financial wellbeing (CFPB, 2017), which belongs to a subjective and multi-item measure. Their definition is consumer-driven and takes into consideration of present vs. future and security vs. freedom of choice factors.

The CFPB conceptual definition of financial wellbeing and its scale measurement were developed after a rigorous process that included consumer interviews, multiple rounds of data collection, and extensive expert input. The CFPB also commissioned a research project to study pathways of financial wellbeing. In that study, the conceptual framework of financial wellbeing was proposed suggesting that financial skills and financial behaviors determine financial situation, then financial situations determine financial wellbeing (CFPB, 2018).

Many factors contribute to consumer financial wellbeing, an important element of overall wellbeing (Easterlin et al., 2010; Rath et al., 2010). Age, education, and financial literacy have 
been found to be positively associated with financial wellbeing (Lusardi \& Mitchell, 2011; Taft et al., 2013). Financial satisfaction is a subjective measure of financial wellbeing. In the wellbeing research literature, financial satisfaction is used as an important indicator of general wellbeing (Diener \& Biswas-Diener, 2002). Previous research has found that financial advice (Xiao \& Porto, 2016), risk tolerance (Joo \& Grable 2004), gender (Hira \& Mugenda, 2000), and desirable financial behaviors (Xiao \& Porto, 2017) are associated with financial satisfaction. Using the CFPB scale of financial wellbeing, researchers find that desirable financial behavior such as using non-retirement savings automated deposits is positively associated with financial wellbeing (Middlewood et al., 2018). Previous research suggests that possible determinants of financial wellbeing are financial capability related factors such as financial knowledge, financial behavior, and perceived financial capability (e.g. Xiao et al., 2014; Xiao \& O’Neill, 2016; Xiao \& Porto, 2017). In this study, we focus on relative contributions of financial capability related factors to consumer financial wellbeing.

\subsection{Financial capability among vulnerable consumers}

The level of consumer financial capability in the United States is worrisome. Most Americans fail to properly prepare for retirement or financial emergencies (Lusardi, 2011), lack of access to appropriate financial products and services (Sherraden, 2013), and lack of financial education (Xiao \& O’Neill, 2016).

Vulnerability is context specific; some people can be experts in one facet of life while being less knowledgeable in other situations. Consumers with low financial capability may be more susceptible to making bad decisions in the financial marketplace. For instance, gullible consumers may lack the necessary financial capability to avoid financial frauds in an 
increasingly complex financial market (Reurink, 2018). Both objective and subjective financial knowledge might help prevent some types of fraud among older Americans, but overconfidence can also lead to poor choices and financial vulnerability (DeLiema et al., 2018).

Young adults scored the lowest in many financial capability components compared to their older counterparts (Xiao et al., 2015). Young adults also display very limited financial literacy (Lusardi et al., 2010). Financial education helps prevent young adult from using payday lending (Harvey 2019) while subjective financial knowledge guides college students to better financial behaviors (Xiao et al., 2014). Financial knowledge is associated with financial behavior (Xiao et al., 2011) and many factors such as parents and financial education help form desirable financial behaviors of young adults (Shim et al., 2010). People living in poverty are more likely to make bad financial decisions due to cognitive pressure (Mani et al., 2013). The ability and opportunity to make good financial choices is a building block for financial capability (Sherraden, 2013). Furthermore, there is a strong association between poverty/low income and inadequate financial capability or its components (Walstad et al., 2017).

Confidence on financial knowledge and on making financial choices is another important indicator to identify vulnerable consumers. Confidence refers to a belief in one's ability to succeed in specific tasks (Bandura, 1977). Financial confidence or financial self-efficacy refers to people who believe that they can manage their finances effectively (Lown, 2011). Some researchers define financial confidence as perceived financial knowledge (Bialowolski et al., 2020) or subjective financial knowledge (Xiao \& Porto, 2017). Confidence levels affect consumer financial behaviors. Underconfident consumers are less likely to seek investment and mortgage advice (Porto \& Xiao, 2016) and less likely to participate in the stock market (Xia et 
al., 2014). Less confident consumers may be more vulnerable than their more confident counterparts in consumer financial decisions and consequences.

In this study, we assume that financial capability has three components: knowledge, behavior, and skill. We examine how each of these factors individually is associated with consumers' financial wellbeing. In addition, we further the analyses by examining how each distinctive financial capability component contributes to financial wellbeing among subsamples especially those who are vulnerable such as the young, poor, underconfident, and defrauded. Based on the above discussions, we propose following the research questions:

1. Which component of financial capability - financial knowledge, financial behavior, or financial skill - is more important for financial wellbeing of the whole sample?

2. Are relative contributions of financial capability components (knowledge, behavior, and skill) to financial wellbeing different among vulnerable and other consumers?

\section{METHODS}

\subsection{Data}

The 2016 National Financial Well-Being Survey data was used. The data set was commissioned by the Consumer Financial Protection Bureau (CFPB, 2017) and is available for public use. The original data set has a sample size of 6,394. After removing observations with missing values in several key variables such as the financial wellbeing variable, the final sample size used was 6,336. The full sample was used in the analyses first. Subsamples in terms of age, poverty status, confidence, and fraud victim status were then used for further analyses. 


\subsection{Measures}

Financial Wellbeing. The financial wellbeing score created by the data owner was used as the dependent variable in the analyses (CFPB, 2017). The score ranged 20-100, in which the higher the score, the better the financial wellbeing.

Financial Capability. The score of financial skills created by the data owner was used. The Knoll/Houts measure was used to measure financial knowledge, which was calculated using the Item Response Theory and provided by the data owner. The financial behavior measure followed the CFPB pathway model approach (CFPB 2018, Appendix D), summarizing the scores of 11 financial behaviors with a score range of 0-55.

Variables Indicating Vulnerabilities. Four variables were used to represent demographic, economic, psychological, and social dimensions, which are age, poverty status, confidence in achieving financial goals, and fraud victim status. Age was measured by three groups, those aged 18-35, 36-61, and 62 or older. Poverty status was measured at three levels, <100\%, 100-199\%, and $200 \%$ or higher Federal Poverty Line (FPL). Goal confidence was measured by three levels, not at all, not very / somewhat, and very confident. Fraud victim status was measured by three levels, yes, no, and not sure. For the confidence and fraud variables, respondents who refused to answer these questions were removed from the analyses due to the small sample sizes that would generate less meaningful results. These variables were used as control variables in the main analyses. As two additional control variables, gender and college education were also employed in the main analyses. Later, they were used for further, detailed analyses when subsample differences were explored. For example, using age as an identifying variable, further analyses 
were conducted among the three age groups to see which financial capability factors are more important in predicting financial wellbeing.

\subsection{Data analyses}

Bivariate analyses were used to explore general patterns. A multivariate OLS regression was used to examine which financial capability factors, knowledge, behavior, or skill was more closely related to financial wellbeing, in which financial wellbeing was the dependent variable, and financial knowledge, financial behavior and financial skill were independent variables. Next, additional analyses in selected subsamples were conducted to examine among different subgroups in terms of age, poverty status, confidence level, and fraud victim status, which financial capability factors were more important for financial wellbeing. All regressions used clustered standard errors at the census division level.

\section{RESULTS}

\subsection{Descriptive statistics of the sample}

Table 1 presents descriptive statistics of the sample and subsamples that showed interesting group differences. All group differences are confirmed by the ANOVA results presented under each group. Financial wellbeing, age, poverty status, and confidence showed positive associations. Additionally, the older, those higher than the Federal Poverty Line, and higher levels of confidence, demonstrated a higher financial wellbeing score. In terms of fraud victim status, consumers who reported "not sure" expressed a much lower score in financial wellbeing than the "yes" or "no" groups. 
The financial knowledge had similar group differences. Age, poverty status, and confidence were positively associated with financial knowledge. The older, those higher than the Federal Poverty Level (FPL), and possessing higher levels of confidence scored higher in financial knowledge. Interestingly, in terms of fraud victim status, consumers who reported "yes" scored the highest in financial knowledge.

For financial behavior, the oldest group scored higher than the young and middle-aged groups. Respondents that rated themselves very confident and those above the 200\% FPL threshold scored the highest on financial behavior. For the fraud victim group, the "yes" group had the highest score, the "no" group had the second highest score, and the "not sure" group had the lowest score in financial behavior.

Financial skill showed similar group patterns. Age, poverty status, and confidence were positively associated with financial skill, implying the older, wealthier, and more confident tended to have higher financial skill. In terms of fraud victim status, both consumers who said "yes" and "no" had higher scores in financial skill than the "not sure" group.

\subsection{Regression results}

In Table 2, coefficients of the independent variables are standardized and included on an Ordinary Least Square regression using the financial wellbeing score as the dependent variable. Column 1 limits the model to the three financial capability variables while Column 2 includes the full model with all control variables. Since the same scale is being used, beta estimates can be compared directly within each model. For example, when financial wellbeing is regressed with three financial capability variables (column 1), betas (estimated standardized coefficients) 
are, in the order from high to low, behavior (4.4), knowledge (3.1), and skill (2.7), implying that on average, behavior contributes the most, knowledge contributes the second most, and skills contributes the least to financial wellbeing.

Adding a set of controls in column 2, financial behavior remains the main contributor to financial wellbeing followed closely by financial skill. In this column, financial knowledge as a financial capability component becomes the least contributor to financial wellbeing. The contributions of financial behavior and financial skills to financial wellbeing are roughly the same in this full model. We tested changes in the coefficients of the three main dependent variable of interest knowledge, skill, and behavior - and found that all changes are significant from the reduced to the full model. This column also includes indicators of gender and educational achievement, two potential sources of vulnerability. While the addition of gender was not significant in the model, those that completed a college degree report higher levels of financial wellbeing.

Column 3 in Table 2 examines the possibility that the financial behavior effect is largely driven by financial knowledge. This column shows a residual row to represent the unexplained portion of financial behavior after regressing financial knowledge. The result show that financial behavior is still a significant contributor to financial wellbeing after taking into consideration the effect of financial knowledge. Post-estimation test results (not shown but available upon requests from the authors) support better fit for the full model compared to the reduced model and variation inflation factors displayed no evidence of severe multicollinearity among independent variables (all VIFs under 2.5). 
Similar to bivariate analyses showed earlier, being older, wealthier, and more confident are factors associated with higher financial wellbeing. Respondents that are aware that they suffered fraud have a lower level of financial wellbeing compared to those unsure of their status.

Regarding the betas, being confident, above the $200 \%$ FPL and over the age of 61 show stronger associations with financial wellbeing. On the other hand, the coefficient of financial knowledge dropped considerably after other variables are incorporated in the model, implying that financial knowledge may have a weaker impact on financial wellbeing when other factors are taking into consideration.

In Table 3, each row represents an OLS regression for each subgroup of vulnerable consumers. The dependent variable remains as financial wellbeing and coefficients are standardized. For young adults (aged 18-35) and the mid-aged (aged 36-61), betas of skill are much smaller, while betas of behavior are much larger, compared to older adults (aged 62 or older). This implies that for the young and middle aged, knowledge and behavior are more important than skill for their financial wellbeing.

Among subsamples regarding poverty status, two factors, knowledge and skill, do not show any statistically significant associations with financial wellbeing among consumers under $100 \%$ and at 100-199\% FPL, while for consumer at 200\%+ FPL, all three financial capability factors (knowledge, behavior, and skill) show significant associations with financial wellbeing. The findings suggest that to improve financial wellbeing of consumers below or near the poverty level, more effective interventions should encourage this population to perform beneficial financial behaviors instead of enhancing their financial knowledge and skill. 
Consumers with different confidence levels also display intriguing patterns in the results. No significant associations appear among the three financial capability factors for consumers not at all confident in their ability to achieve their financial goals. In contrast, all three factors (knowledge, behavior, and skill) show associations to financial wellbeing for those rated themselves as either not very/somewhat or very confident. Again, a comparison across groups reveal that very confident consumers rely more heavily on their knowledge and skills while the middle group (not very/somewhat confident) count on their financial behavior the most.

The findings suggest that confidence is a critical factor for improving financial wellbeing. If a person has no confidence to achieve their financial goals, all interventions for knowledge, behavior, and skill may not be effective. Professionals working with this type of consumer should first develop strategies to boost their confidence before helping them enhance their knowledge, behavior, and skill.

The fraud victim status shows some differences. Consumers who answered "not sure" about their fraud status had the lowest betas of the three financial capability variables compared to consumers who said "yes" or "no." This leads to the possibility that unsure consumers might need to seek or receive reliable information regarding their fraud status before their financial capability can better impact their financial wellbeing.

Comparing the results of consumers with or without college education, financial behavior appears more important for both groups since they have the largest betas compared to those of financial knowledge and financial skill. The only difference can be observed is that among college educated consumers, betas of behavior and skill have similar sizes, suggesting for this group, both behavior and skill are important. 


\section{DISCUSSION}

This study used a large scale, nationally representative data in the U.S. to examine relative contributions of three financial capability components to financial wellbeing in the whole sample and several subsamples in terms of age, poverty status, confidence, and fraud victim status. This study selectively chose several representative factors to identify which financial capability components are more important for vulnerable populations. These factors are for demonstration purposes and the similar approach may be expanded to identify other important factors used for categorizing vulnerable consumers in future research and practice. The findings suggest that three components of financial capability in the whole sample have differential relative contributions to financial wellbeing, in which financial behavior contributes the most, financial skill contributes the second most, and financial knowledge contributes the least to financial wellbeing. The results also show when vulnerable subsamples are examined, more important financial capability factors relevant to financial wellbeing can be identified and used in educational practice.

In the oldest age group, financial skill contributes the most to financial wellbeing, while among the young and middle-aged groups, financial behavior contributes the most to financial wellbeing. When poverty status subsamples are examined, only financial behavior contributes to financial wellbeing in all subsamples according to FPL guidelines. For those living in poverty or near poverty, financial knowledge and skill do not show associations with financial wellbeing. When confidence subsamples are examined, both confident and very confident consumers benefit from all three financial capability components on their financial wellbeing while only financial behavior displays a positive association for the least confident group. Finally, in terms 
of fraud victim status, financial behavior contributes the most to financial wellbeing in the "yes," "no," and "not sure" subgroups.

Limitations of this study should be acknowledged. First, this study used cross-sectional data that can only be used to examine associations between financial capability factors and financial wellbeing. No causality should be assumed but some interesting patterns may be informative for designing financial education programs to target consumers with diverse needs, especially those who are vulnerable. The second limitation is that the data is from only one country. In future research, data from other countries can be used to confirm or disconfirm some findings of this study. Third, the skill measured used by CFPB is different from other researchers (e.g. Bialowolski et al., 2020). How to accurately measure financial skill can be addressed in future research. Fourth, vulnerable consumers in more dimensions such as education and gender can also be examined in future research.

Results of this study have direct implications for consumer financial education program design and delivery. First, the results suggest that financial behavior may contribute the most to financial wellbeing. As such, when financial education programs are designed, besides effectively conveying knowledge, educators also need to consider adding activities and assignments to encourage students to engage in desirable financial behaviors to help improve their financial wellbeing. Second, consumer educators should pay attention to segments of vulnerable consumers such as the poor or less confident consumers and emphasize action taking in education programs. Third, for consumers who are least confident, education programs may emphasize how to raise their confidence as the beginning learning objective before offering other education activities to enhance their knowledge, behavior, and skill. Fourth, educators need to 
consider different educational needs of consumers of different ages. For young and middle-aged consumers, education may focus on financial skill besides enhancing their knowledge and behavior. For older consumers, educators may encourage them to share their financial skills with their peers, either of the same age or younger. Fifth, our results show that fraud victims have higher financial knowledge and better financial behavior, which means knowledge and behavior of preventing frauds may be different from knowledge and behavior in money management. Educators may need to provide them information about fraud prevention related knowledge and behaviors. Also, the results show that consumers who are "not sure" if they are fraud victims have lower level of financial knowledge, behavior, and skill. Educators may use this fact as a clue to identify people who have lower financial capability and provide the special financial education they need. 


\section{References}

Atkinson, A., McKay, S., Collard, S., \& Kempson, E. (2007). Levels of financial capability in the UK. Public Money and Management, 27(1), 29-36. https://doi.org.10.1111/j.14679302.2007.00552.X

Baker, S. M., Gentry, J. W., \& Rittenburg, T. L. (2005). Building understanding of the domain of consumer vulnerability. Journal of Macromarketing, 25(2), 128-139. doi: $10.1177 / 0276146705280622$

Bandura, A. (1977). Self-efficacy: Toward a unifying theory of behavior change. Psychological Review, 84, 191-215.

Białowolski, P., Cwynar, A., \& Cwynar, W. (2020). Decomposition of the financial capability construct: A structural model of debt knowledge, skills, confidence, attitudes, and behavior. Journal of Financial Counseling and Planning, Early View. https://doi.org/10.1891/JFCP-19-00056

CFPB. (2017). Financial wellbeing in America. Washington, DC: Consumer Financial Protection Bureau.

CFPB. (2018). Pathways of financial wellbeing: The role of financial capability. Washington, DC: Consumer Financial Protection Bureau.

Commuri, S., \& Ekici, A. (2008). An enlargement of the notion of consumer vulnerability. Journal of Macromarketing, 28(2), 183-186. doi: 10.1177/0276146708316049

Coppack M., Raza Y., Sarkar S., \& Scribbins, K. (2015). Financial Conduct Authority. Consumer vulnerability. Occasional Paper No, 8 .

DeLiema, M., Deevy, M., Lusardi, A., \& Mitchell, O. S. (2018). Financial Fraud among Older Americans: Evidence and Implications (No. w24803). National Bureau of Economic Research. 
Diener, E., \& Biswas-Diener, R. (2002). Will money increase subjective well-being? Social Indicators Research, 57(2), 119-169.

Easterlin, R. A., McVey, L. A., Switek, M., Sawangfa, O., \& Zweig, J. S. (2010). The happiness-income paradox revisited. Proceedings of the National Academy of Sciences, 107(52), 22463-22468.

Harvey, M. (2019). "Does State-Mandated Financial Education Affect High Cost Borrowing?" Insights: Financial Capability. Washington, DC: FINRA Investor Education Foundation.

Hilgert, M. A., Hogarth, J. M., \& Beverly, S. G. (2003). Household financial management: The connection between knowledge and behavior. Federal Reserve Bulletin, 89, 309-322.

Hill, R. P., \& Sharma, E. (2020). Consumer vulnerability. Journal of Consumer Psychology.

Hira, T. K., \& Mugenda, O. (2000). Gender differences in financial perceptions, behaviors and satisfaction. Journal of Financial Planning, 13(2), 86-93.

Huston, S. (2010). Measuring financial literacy. Journal of Consumer Affairs, 44, 296-316.

Johnson, E., \& Sherraden, M. S. (2007). From financial literacy to financial capability among youth. Journal of Sociology and Social Welfare, 34(3), 119-145.

Joo, S. (2008). Personal financial wellness. In J. J. Xiao (Ed.), Handbook of consumer finance research (pp. 47-68). New York: Springer.

Joo, S., \& Grable, J. E. (2004). An exploratory framework of the determinants of financial satisfaction. Journal of Family \& Economic Issues, 25(1), 25-50.

Lin, J. T., Bumcrot, C., Ulicny, T., Lusardi, A., Mottola, G., Kieffer, C., \& Walsh, G. (2016). Financial capability in the United States 2016. Washington, DC: FINRA Investor Education Foundation.

Lown, J. M. . (2011). Development and validation of a financial self-efficacy scale. Journal of Financial Counseling and Planning, 22(2), 54-63. 
Lusardi, A. (2011). Americans' financial capability (No. w17103). National Bureau of Economic Research.

Lusardi, A., \& Mitchell, O. S. (2011). Financial literacy and planning: Implications for retirement wellbeing (No. w17078). National Bureau of Economic Research.

Lusardi, A., \& Mitchell, O. S. (2014). The economic importance of financial literacy: Theory and evidence. Journal of Economic Literature, 52(1), 5-44.

Lusardi, A., Mitchell, O. S., \& Curto, V. (2010). Financial literacy among the young. Journal of Consumer Affairs, 44(2), 358-380.

Mani, A., Mullainathan, S., Shafir, E., \& Zhao, J. (2013). Poverty impedes cognitive function. Science, 341(6149), 976-980.

Mick, D. G., Pettigrew, S., Pechmann, C., \& Ozanne, J. L. (2012). Transformative consumer research for personal and collective well-being. New York, NY US: Routledge/Taylor \& Francis Group.

Middlewood, B. L., Chin, A., Johnson, H., \& Knoll, M. A. Z. (2018). Exploring the relationships between impatience, savings automation, and financial welfare. Financial Planning Review, 1: e1020. doi.org/10.1002/cfp2.1020

Porto, N., \& Xiao, J. J. (2016). Financial literacy overconfidence and financial advice seeking. Journal of Financial Service Professionals, 70(4).

Rath, T., Harter, J. K., \& Harter, J. (2010). Wellbeing: The five essential elements. Simon and Schuster. New York, NY.

Reurink, A. (2018). Financial fraud: A literature review. Journal of Economic Surveys, 32(5), 1292-1325.

Robb, C. A., \& Woodyard, A. (2011). Financial knowledge and best practice behavior. Journal of Financial Counseling and Planning, 22(1), 60-70. 
Shapiro, G. K., \& Burchell, B. J. (2012). Measuring financial anxiety. Journal of Neuroscience, Psychology, and Economics, 5, 92-103.

Sherraden, M. S. (2013). Building blocks of financial capability. Financial education and capability: Research, education, policy, and practice, 3-43.

Shim, S., Barber, B. L., Card, N. A., Xiao, J. J., \& Serido, J. (2010). Financial socialization of first-year college students: The roles of parents, work, and education. Journal of Youth and Adolescence, 39(12), 1457-1470. https://doi.org/10.1007/s10964-009-9432-x

Taft, M. K., Hosein, Z. Z., Mehrizi, S. M. T., \& Roshan, A. (2013). The relation between financial literacy, financial wellbeing and financial concerns. International Journal of Business and Management, 8(11), 63-75.

Tang, N., Baker, A., \& Peter, P. C. (2015). Investigating the disconnect between financial knowledge and behavior: The role of parental influence and psychological characteristics in responsible financial behaviors among young adults. Journal of Consumer Affairs, 49(2), 376-406.

Taylor, M. (2011) Measuring financial capability and its determinants using survey data. Social Indicators Research, 102, 297-314.

Walstad, W., Urban, C., Asarta, C., Breitbach, E., Bosshardt, W., Heath, J., O’Neill, B., Wagner, J., \& Xiao, J. J. (2017). Perspectives on evaluation in financial education: Landscape, issues, and studies. Journal of Economic Education, 48(2), 93-112.

Xia, T., Wang, Z., \& Li, K. (2014). Financial literacy overconfidence and stock market participation. Social Indicators Research, 119(3), 1233-1245.

Xiao, J. J. (2015). Consumer economic wellbeing. New York: Springer.

Xiao, J. J., \& O’Neill, B. (2016). Consumer financial education and financial capability. International Journal of Consumer Studies, 40(6), 712-721. 
Xiao, J. J., \& Porto, N. (2016). Which financial advice topics are positively associated with financial satisfaction. Journal of Financial Planning, 29(7), 52-60.

Xiao, J. J., \& Porto, N. (2017). Financial education and financial satisfaction: Financial literacy, behavior, and capability as mediators. International Journal of Bank Marketing, 35(5), 805-817.

Xiao, J. J., Ahn, S. Y., Serido, J., \& Shim, S. (2014). Earlier financial literacy and later financial behavior of college students. International Journal of Consumer Studies, 38(6), 593-601.

Xiao, J. J., Chen, C., \& Chen, F. (2014). Consumer financial capability and financial satisfaction. Social Indicators Research, 118(1), 415-432.

Xiao, J. J., Chen, C., \& Sun, L. (2015). Age differences in consumer financial capability. International Journal of Consumer Studies, 39(4), 387-395.

Xiao, J. J., Serido, J., \& Shim, S. (2011a). Financial education, financial knowledge, and risky credit behavior of college students. In D. J. Lamdin (Ed.). Consumer knowledge and financial decisions: Lifespan perspectives (pp. 113-128). Springer.

Xiao, J. J., Tang, C., Serido, J., \& Shim, S. (2011b). Antecedents and consequences of risky credit behavior among college students: Application and extension of the theory of planned behavior. Journal of Public Policy \& Marketing, 30, 239-245.

Xiao, J. J., Tang, C., Serido, J., \& Shim, S. (2011). Antecedents and consequences of risky credit behavior among college students: Application and extension of the theory of planned behavior. Journal of Public Policy \& Marketing, 30(2), 239-245. https://doi.org/10.1509/jppm.30.2.239 
TABLE 1 Descriptive Statistics of the Sample and Subsamples with One-Way ANOVA*

\begin{tabular}{|c|c|c|c|c|c|}
\hline & $\begin{array}{c}\text { Financial } \\
\text { Wellbeing } \\
(20-100)\end{array}$ & $\begin{array}{c}\text { Financial } \\
\text { Knowledge } \\
(1-16)\end{array}$ & $\begin{array}{c}\text { Financial } \\
\text { Behavior } \\
(0-55)\end{array}$ & $\begin{array}{c}\text { Financial } \\
\text { Skill } \\
(\mathbf{5 - 8 5})\end{array}$ & $\mathbf{N}$ \\
\hline All & 56.08 & 11.03 & 42.52 & 50.778 & 6,336 \\
\hline \multicolumn{6}{|l|}{ Age } \\
\hline $18-35$ & 51.19 & 10.24 & 40.80 & 50.24 & 1,530 \\
\hline $36-61$ & 53.80 & 11.00 & 41.82 & 50.25 & 2,611 \\
\hline Over 61 & 62.40 & 11.62 & 44.48 & 51.75 & 2,253 \\
\hline \multicolumn{6}{|l|}{ ANOVA } \\
\hline F-test & 388.36 & 153.16 & 126.34 & 10.52 & \\
\hline$P($ value $)$ & 0.000 & 0.000 & 0.000 & 0.000 & \\
\hline \multicolumn{6}{|l|}{ Poverty status } \\
\hline$<100 \mathrm{FPL}$ & 45.33 & 8.64 & 38.68 & 46.71 & 661 \\
\hline 100-199\% FPL & 49.24 & 9.79 & 40.36 & 47.41 & 859 \\
\hline $200+\%$ FPL & 58.73 & 11.57 & 43.41 & 51.93 & 4,874 \\
\hline \multicolumn{6}{|l|}{ ANOVA } \\
\hline$F$-test & 429.30 & 663.18 & 155.95 & 88.32 & \\
\hline$p($ value $)$ & 0.000 & 0.000 & 0.000 & 0.000 & \\
\hline \multicolumn{6}{|l|}{ Goal confidence } \\
\hline Not all confident & 33.49 & 8.15 & 27.98 & 33.34 & 129 \\
\hline Not very/somewhat & 51.21 & 10.47 & 40.08 & 46.24 & 3,770 \\
\hline Very confident & 64.73 & 12.07 & 47.17 & 58.67 & 2,467 \\
\hline \multicolumn{6}{|l|}{ ANOVA } \\
\hline F-test & 1170.36 & 478.91 & 1243.01 & 1181.87 & \\
\hline$p($ value $)$ & 0.000 & 0.000 & 0.000 & 0.000 & \\
\hline \multicolumn{6}{|l|}{ Fraud victim status } \\
\hline no & 56.57 & 11.00 & 42.80 & 51.20 & 4,161 \\
\hline yes & 56.89 & 11.62 & 43.38 & 51.38 & 1,686 \\
\hline not sure & 49.63 & 9.48 & 38.23 & 45.57 & 512 \\
\hline \multicolumn{6}{|l|}{ ANOVA } \\
\hline$F$-test & 60.20 & 163.70 & 96.58 & 49.22 & \\
\hline$p$ (value) & 0.000 & 0.000 & 0.000 & 0.000 & \\
\hline
\end{tabular}

Source: CFPB 2016 National Financial Well-Being Survey

* ANOVA results display results of each vulnerable group categories as factors on each financial capability variable. For example, under the Financial Wellbeing column, the Age group results show a statistically significant difference between groups $(F(2,6386)=388.36, p=0.000)$. Degrees of freedom vary slightly between vulnerable groups due to missing data. 
TABLE 2 Results of OLS Regressions on Financial Wellbeing - Standardized Coefficients.

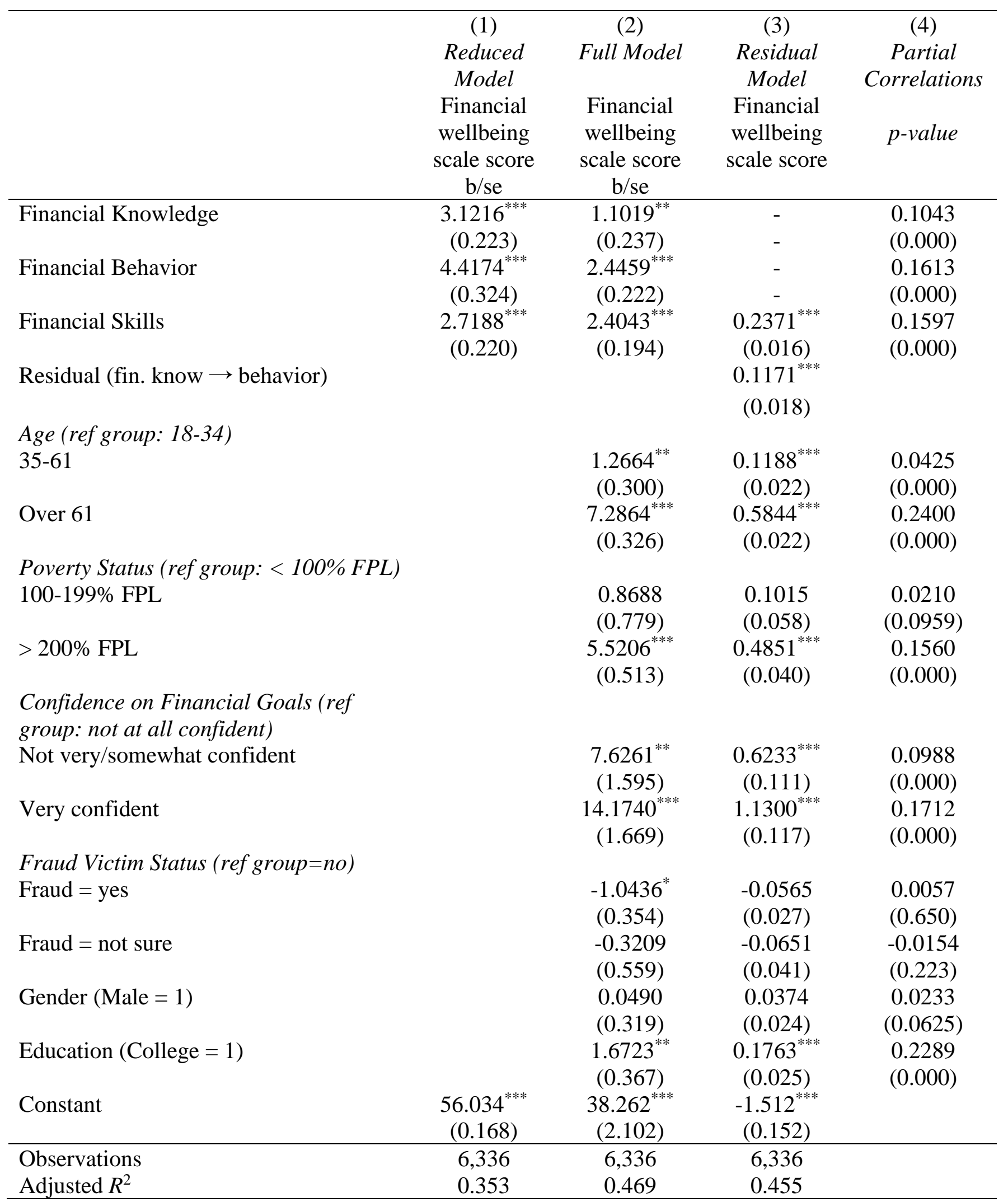

Source: CFPB 2016 National Financial Well-Being Survey

${ }^{*} p<0.05,{ }^{* *} p<0.01,{ }^{* * *} p<0.001$ 
TABLE 3 Summary of Results of OLS Regressions on Financial Wellbeing - Standardized Coefficients.

\begin{tabular}{|c|c|c|c|c|c|}
\hline & $\begin{array}{c}\text { Knowledge } \\
\text { beta }\end{array}$ & $\begin{array}{c}\text { Behavior } \\
\text { beta }\end{array}$ & $\begin{array}{l}\text { Skill } \\
\text { beta }\end{array}$ & $\mathrm{n}$ & $\begin{array}{c}\text { Adjusted } \\
\mathrm{R}^{2} \\
\end{array}$ \\
\hline All & $3.1260^{* * *}$ & $4.4173^{* * *}$ & $2.7188^{* * *}$ & 6,336 & 0.353 \\
\hline \multicolumn{6}{|l|}{ Age } \\
\hline $18-35$ & $2.7124^{* * *}$ & $3.4831^{* * *}$ & $1.851^{* * *}$ & 1,530 & 0.292 \\
\hline $36-61$ & $2.1883^{* * *}$ & $4.9692^{* * *}$ & $1.9404^{* * *}$ & 2,611 & 0.340 \\
\hline Over 61 & $2.6920^{* * *}$ & $2.6985^{* * *}$ & $5.9017^{* * *}$ & 2,253 & 0.383 \\
\hline \multicolumn{6}{|l|}{ Poverty status } \\
\hline$<100 \mathrm{FPL}$ & 0.4144 & $4.3609^{* * *}$ & 0.4251 & 661 & 0.166 \\
\hline 100-199\% FPL & 0.9429 & $4.4075^{* * *}$ & 0,8822 & 859 & 0.200 \\
\hline $200+\%$ FPL & $2.3230^{* * * *}$ & $4.2330^{* * * *}$ & $3.7829^{* * * *}$ & 4,874 & 0.354 \\
\hline \multicolumn{6}{|l|}{ Goal confidence } \\
\hline not all confident & -2.1031 & 1.1285 & -0.6560 & 129 & 0.013 \\
\hline not very/somewhat & $2.0574^{* * *}$ & $4.5023^{* * *}$ & $0.6707^{*}$ & 3,770 & 0.167 \\
\hline very confident & $4.1457^{* * *}$ & $1.7778^{* * *}$ & $2.9195^{\text {*** }}$ & 2,467 & 0.202 \\
\hline \multicolumn{6}{|l|}{ Fraud victim } \\
\hline no & $3.1547^{* * *}$ & $4.6851^{* * *}$ & $2.5895^{* * *}$ & 4,161 & 0.355 \\
\hline yes & $3.8745^{* * *}$ & $4.3515^{* * *}$ & $2.6498^{* * *}$ & 1,686 & 0.339 \\
\hline Not sure & $2.0654^{* * *}$ & $4.1858^{* * *}$ & $1.7491 * *$ & 512 & 0.295 \\
\hline \multicolumn{6}{|l|}{ Education } \\
\hline No College & $2.7035^{* * *}$ & $4.6871^{* * *}$ & $2.0515^{* * *}$ & 3.944 & 0.3086 \\
\hline College Graduate & $2.7210^{* * *}$ & $3.9754^{* * *}$ & $3.9480^{* * *}$ & 2,392 & 0.3529 \\
\hline
\end{tabular}

Source: CFPB 2016 National Financial Well-Being Survey

${ }^{*} p<0.05,{ }^{* *} p<0.01,{ }^{* * *} p<0.001$

Note: Each row reports standardized coefficients estimates of a regression model. For example, in the row of "All," the whole sample is used and estimated coefficients of three independent variables, financial knowledge, behavior, and skill, are .2219, .3140, and .1933, respectively, implying that behavior has the largest, skill has the middle and knowledge has the smallest contribution to financial wellbeing. Statistics in other rows can be interpreted in similar way. 